Journal of Social Sciences 6 (3): 340-349, 2010

ISSN 1549-3652

(C) 2010 Science Publications

\title{
Study of Tourists' Rights in Iran with Emphasis on Urban Tourist Rights
}

\author{
${ }^{1}$ Ahmad PourAhmad, ${ }^{1}$ Mohammad Shabanifard, ${ }^{1}$ Ali Hosseini and ${ }^{2}$ Omid Soltanipour \\ ${ }^{1}$ Department of Geography and Urban Planning, University of Tehran, \\ Allay Azin, Qouds Str., Enghlab Ave., Tehran, Iran \\ ${ }^{2}$ Department of Rural Development, Payame Noor University, Iran
}

\begin{abstract}
Problem statement: Achieving stability in a tourism system which includes tourism supply and demand needs wise legal supports in urban tourism industry. In case of presence of proportional legal supports, urban tourism system can help prevent from confusion in city system as an effective means for balanced and sustainable development of the city. Approach: This article aimed at recognition, study and evaluation of urban tourism indexs and legal supports for tourists in Iran. Results: In Juridical book, a right of non-Muslims, in one way, has been classified into three groups: Zemmi, Moahed and Mostaman. In Iran, for different reasons such as regional unity and tourism treaties, the idea of granting more liberties to them has developed. Conclusion: These ignoring variables, do pose Iran's tourism industry rules and regulations in an appropriate position and this has caused our country, which is among the highly potential tourism countries for competition in the international arena, gains little income from this economic activity.
\end{abstract}

Key words: Urban tourism, tourists, tourists' rights, Iran

\section{INTRODUCTION}

Since human being abandoned the migrating and nomadic life and settled in villages and towns and formed more extensive communities, in other words when civilization started and labor division occurred and relations between humans became more and complex, the necessity for regulating the relations between individuals became evident. The first legal rules were approved and gradually by extension of communities and formation of many trades and professions, the necessary social institutions were established and finally led to the emergence of a strong organ on top of the social organizations which was called government.

Then, the government, according to the interests of the ruling classes, became the source of governing regulations on extraterritorial relations. Rules and regulations were enacted proportionate to the growth of productions, religious beliefs, ethical principles, trade regulations, cultural indices, custom and usage. The governing body made use of them to maintain its dominance and community order (Gratner, 1996). The historical development of societies shows that each society and country which had rules and regulations proportionate to social needs of the community and government and people had obligation to respond and correct execution of law, have advanced more rapidly. This brief introduction is just to pose the subject, otherwise the topic of law and the culture of respect to law, could be the subject of many discussions and seminars, which its necessity is felt more than ever. What is essential to be mentioned here is that nowadays law and enactment of regulations shows its effects in all aspects of life whether cultural, economic and ethical and even in some cases, economic and cultural issues are taken under control by enactment of laws.

Tourism is among the issues which are of cultural and economic importance and governments pay attention to it. The governments enact regulations to guide this industry in the direction of their goals by prioritizing each of these dimensions and considering produced effects and results.

Tourism is considered a component of development in modern world (Papoli Yazdi and Saghai, 2009). Today, countries intending to increase economic development recognize the tourism as a component by which they can solve their complicated economic, social, cultural and even political problems. It is for this reason that most countries look at the tourism as a necessity and make use of all their capacities and facilities to get to their intended interests and privileges. The most important space among different destinations attracting the domestic and

Corresponding Author: Ahmad PourAhmad, Department of Geography and Urban Planning, University of Tehran, Allay Azin, Qouds Str., Enghlab Ave., Tehran, Iran 


\section{J. Social Sci., 6 (3): 340-349, 2010}

foreign tourists is cities. From the old times, urban spaces have been the most attractive spaces because the cities are the most advanced and perfect habitats of humans which involve economic, scientific, entertainment and medical centers and even enjoy natural attractions, so are the most important centers of attracting tourists.

\section{Question of the research:}

\section{What are legal supports for tourists in Iran?}

Historical development of tourism industry: Before speaking about the rules the governments consider in tourism development, it is suitable to mention briefly about historical development of tourism industry.

At first, tourism began by trading and businessmen travelled for months and years to take their goods to other countries. This was all the story of tourism in old days (Mohaghegheh Damad, 1998).

Emergence and development of industry, inventing of vehicles, providing more security, improvement of transporting facilities between cities and countries, increasing of incomes and effect of economic, political and social growth paved the way for tourism development. Provision for travelling with better and more desirable facilities is increasing day by day to the extent that at the time being its direct effect on economic improvement has been accepted as an effective principle in economy.

Today, tourism, regardless of its cultural and social dimensions is considered as one of the profitable economic factor in the world to the extent that economies of some of the countries are based on this new industry (Hall and Page, 2006; Page and Hall, 2003).

Iran also has geographically appropriate location and enjoys countless divine blessings, natural and cultural gifts and by best use of these divine blessings, different weather, natural sceneries, mountains, beautiful and famous castles, historical monuments, shrines and holy places can achieve the goal of increasing the entrance of foreign currency and introduce Islamic culture to other countries.

As mentioned earlier, tourism has a long history in the world and in Quran and Nahjolbalaghe also there is an indication to this important issue and people are encouraged to travel. From the historical background point of view, what is important to be considered in this article is concerned to Iran in the recent century.

Tourism in Iran was formed by establishing office of "tourism affairs" in interior ministry to provide facilities for development and expansion of this industry. In 1964, office of tourism affairs was replaced by "supreme council of tourism" until 1964 when establishment of tourist attraction organization was approved by the cabinet. Later the Iran touring and tourism affairs were managed under the supervision of ministry of information and tourism by four joint stock companies named Iran's tourism facilities, Iran's tours, Iran's homes center, organization of tourism centers for winter sports, until 1980 after the victory of Islamic revolution when to prevent from intervention of responsibilities of the four mentioned companies and to coordinate all activities and issues related to tourism, the merger of these four companies was approved according to the sanctioned law of 12 November 1980 by revolution council. And organization of Iran touring and tourism centers with new combination and with distinguished policy and goals started its activity with initial capital of 25,693,000 Rials to run 144 reception units and to provide tourism services.

In 1980, the new memorandum of the organization was provided and later it was changed regarding the current constitution. After these changes on the basis of sanctioned law of 8 February 1980 by revolution council, purchasing and running hotels belonged to Alavi Foundation was submitted to organization of Iran touring and tourism centers. This action increased the level of operations of this organization broadly and increased the capital of the organization considerably and also added to its obligations. Problems resulted from the merger and objection of budget and planning organization paved the way for approving another regulations until 1983 when according to the sanctioned law of number 11384 dated 5 April 1983, running of the hotels under the control of organization of Iran touring and tourism centers was returned again to Mostazafan Foundation (Alavi Foundation) and office of Iran touring and tourism, one of the offices subjected to ministry of Islamic culture and guidance, was established in 1981 to create coordination, pricing tourism facilities of the country including private or state owned, making international connections with foreign tourism organs and institutions, participating in seminars, exhibitions and international tourism meetings, providing booklets and maps for the guidance of domestic and foreign tourists, controlling travelling agencies, development and expansion of Iran touring and tourism promotion across the country. In 1980, on the basis of cabinet sanctioned law, managing affairs of Kish development organization was granted to organization of Iran touring and tourism and then due to some problems, this organization was again separated from the organization of Iran touring and tourism in 1983. In this direction in 29 October 1992, the law of development of Iran touring and tourism industry was approved in order to determining the Iran touring and 


\section{J. Social Sci., 6 (3): 340-349, 2010}

tourism policies and creating coordination between affiliated bodies. And supreme council of Iran touring and tourism presided over by deputy of president and membership of ministries of Islamic culture and guidance, foreign affairs, economy and fiancé, culture and higher education, roads and transportation, Iran Department of Environment, plan and budget organization was held. Affairs of tourism industry were managed in this manner until 13 January 2004 when the law of establishment of cultural heritage and tourism organization was approved by Parliament in an open session and was notified by president to Presidential Institution and Ministries of Islamic culture and guidance and management and planning organization for execution. This law consists of 12 articles and 7 notes. According to article one, cultural heritage organization and Iran touring and tourism organization is separated from ministry of Islamic culture and guidance and from their merger, organization of cultural heritage and tourism is established under the supervision of president with all authorities and responsibilities of the mentioned organization which they had by virtue of different rules and regulations and all facilities and properties and manpower. The head of the organization is appointed by the president (Ghanami et al., 2008).

Definition of some terms of tourism: Standardization of the terms causes the involved people and related groups use similar terms so that distortion and misuse is prevented (Kazemi, 2007).

Tourism: In the law of development of Iran touring and tourism industry approved by parliament, it has been said: "Iran touring and tourism is any kind of individual or group travelling lasting more than 24 hours and is not intended for business" (Article 1) (Mohaghegheh Damad, 1998). Regardless of several definitions presented, many of the researches, thinkers and international scientific research institutions have accepted the technical definition of world tourism organization. In this article the same definition will be considered. All travels resulting in staying at least one night at the destination, but the time being away from home should not be more than one year (World Tourism Organization, 1995).

Tourist: World Tourism Organization in a complete definition has defined the tourist as: "a person who travels to a country other than his/her homeland or usual environment for duration at least one night and less than one year and he/she is not intended to work or make money". This definition includes people who travel in order to leisure, spending holidays, visiting friends and relatives, doing business and professional affairs, treatment, pilgrimage or other goals (Gee and Fayos Sola, 2000).

Tourism system: Generally, tourism system is formed by combination of two main groups of factors i.e. supply and demand. Each one of the mentioned two groups of factors with their subsets forms an extensive system of tourism activities through connection with other factors and subsets. In tourism, demand factor includes internal, international markets and local residents of the destination which use resources and products of tourism. Supply factors in tourism system include attractions, activities, staying facilities, transportation and other tourism facilities and services. On the whole, two groups of factors, supply and demand, affect on the activity trend of this system. One of these cases is legal act state structure which affect on the whole trend of tourism activity in supply and demand sector and the other case is travelling agencies and distribution channels connecting demand sector on behalf of tourists and supply (Jansen and Lievois, 2002).

Tourism destinations: Destinations can be considered as the concentration place of facilities and services, designed for providing the needs of tourists. One of the most important sectors of the tourism system is destinations. Destinations are places where attractions and all facilities needed for tourists are found (Cooper and Shepherd, 1998).

Tourism from the destination place point of view:

- Urban destinations

- Rural destinations

- Nomadic, ethnic and tribal destinations (realms or spaces conserved for Indians)

- Destinations in nature

- Coastal destinations

- Mountainous destinations

- Aerospace destinations

- Environmental destinations (Papoli Yazdi and Saghai, 2009)

Urban tourism: One of the most important destinations affecting the tourism trends in past decades is urban centers. Short period travels have changed these destinations into one of the most major tourism centers. Currently, urban tourism is limited to relatively few cities and is very competitive (Taghavi and Akbari, 2009). In Iran it can be mentioned to Isfahan, Shiraz and Mashhad as major city tourism destinations (Dinari, 2006). 
Cities usually have various and big attractions including museums, memorial buildings, sport stadiums, theatres, parks, buying centers, areas with historical architecture and places related to important events or renowned persons which itself attract many tourists. At the same time with tourism development in urban areas, to meet tourists' needs, more supportive services such as restaurants are built. Visitors coming from outside the city, of course, are not the only people who make use of these facilities but also people of the city itself enjoy them (Hataminejad and Shabanifard, 2007).

To understand the different dimensions of urban tourism, the environment of the city itself with tourists should be considered as a system (Fig. 1).

In this article to enter the discussion i.e., studies of tourists' rights in Iran, the legal supports are addressed on the basis of the Fig. 1 showing the urban tourism system.

Reviewing the international law of tourism: It can strongly be stated that based on the sovereignty principle, governments act according to their independent and specified policies to restrict or encourage the freedom of entering foreign nationals. Thus, currently, governments have different and specified laws and views concerning the issue of freedom, prohibition or restriction of entering foreign nationals.

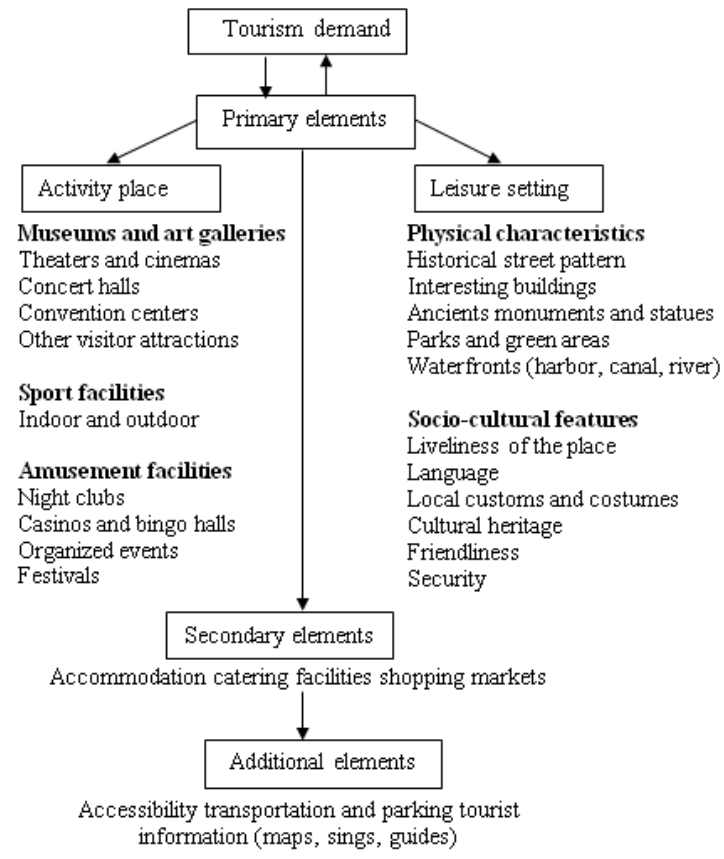

Fig. 1: Urban tourism system
Viewpoint of international law: There are two opinions in the international law on the issue of freedom of and allowing foreigners to enter the country. Some favor of exerting limitation on acceptance and others favor of unconditional freedom of entrance of foreigners to the country. They totally form two general theories:

Theory of necessity of exerting limitation on acceptance of foreigners to the country: Followers of this theory believe that governments are obviously free to accept or not accept the entrance of foreigners to the country. It means that they can use this freedom extensively and unlimitedly. According to this theory if the countries do not have any special treaty between them, they will not be obligated to accept foreign nationals to their territory. The generality of this theory has been verified by international law institution in Genève. But at the time of verifying the mentioned theory in 1928, has added an addendum to it which stresses.

Regardless of such a freedom for the government, justice principle orders that countries do not misuse this right and use it as a limiting principle for entrance or staying freedom of foreigners just in cases where the country is really at the risk of a potential danger (Nasiri, 2004).

Theory of unconditional entrance freedom of foreigners to the country: Followers of this theory believe that the governments cannot on their will prevent from entrance, exit, or staying of nationals in the country or maintain limitations. Followers of this theory in the framework of international law consider the entrance of a foreigner to another country a right and a duty for that country. Such mentality, in fact, originated from natural rights. With a look at the history, human's life is thought that at first everything was common and this partnership was not under any terms. All could travel everywhere easily and without any obstacle. Afterwards, by expiring communal ownership and prevalence of personal ownership, this liberty did not fade away and still remained, because shifting communal ownership to personal ownership has not involved hindering from liberty of relations between humans (Nasiri, 2004).

General policy of governments: At the moment, most governments believing in necessity of providing least rights of foreigners have recognized the freedom of entrance, movement and staying as a principle for foreign nationals. There is not any fixed criterion about it and its determination depends on the attitude of 
governments. Therefore, governments do not accept unconditional freedom and require observing formalities for foreign nationals and stipulate conditions.

What is important in performing this policy in international nationals is rejection of application for acceptance of a foreigner to the country, which in principle must be done individually. It means if a government announces its borders closed to all foreigners or to nationals of one or several countries, such an action can be in conflict with standards of international law. In fact, exerting unnecessary limitations and without logical justification is misusing of sovereignty right with purpose of harming others or if without acceptable reasons, creates a sort of disorder in friendly relations between international community. Moreover, in practice, between a foreigner whose entrance has already been accepted and a foreigner who enters the country for the first time, they maintain a kind of difference in favor of the former one, which such a policy is in conformity with the concept of acquired right (Khaliliyan, 1984).

At the present era the common reason for not accepting a foreigner to a country that has been stipulated as fixed and general regulations in the law of the countries include:

- Suffering from a serious and contagious disease

- Confinement and insanity

- Deported foreigners

- Offenders or perpetrators of illegal acts incompatible with chastity

Islam policy: Every human has the right to freely travel from one place to another and when necessary select his/her habitat inside or outside Islamic cities and countries. Any person who is destitute and downtrodden in a society can take refuge in another community. It is compulsory for every society to give shelter and secure his/her place whenever there is a refuge" (Jafari Tabrizi, 2007). It should be mentioned that there is a different view about a national and foreigner. From Islam's point of view, a person is called a foreigner who is not a Muslim. Thus all Muslims of the world can be considered as nationals (in the sense of unit nation). It seems there is not any evident limitation for Muslims to travel in Muslim countries. Foreigners also by acquiring, "Aman" (quarter), or provided for themselves freely travelling to or staying at Islamic countries. In fact, "Aman" is a passport and staying in Islamic countries which is synonymous with today's visa. It is also a kind of taking asylum. It means "Mostaman" was secured by
Islam according to the immunity treaty (Ziyaye Bigdeli, 2002).

\section{Policy of Islamic republic of Iran's law:}

Iranian nationals: Iran's law in normal conditions recognizes the right of sightseeing, travelling and choosing housing inside the country for everybody. So all Iranians can enjoy this freedom and use it as the case may be, this freedom governs in normal conditions and if general order, unpredictable events and public health demand, the government has the right to limit and decrease it.

Foreign nationals: Foreign nationals has the liberty to enter Iran and stay wherever they like and this liberty is stipulated to get a visa and taking a residence permit from related authorities. Thus a foreign national when enter Iran, first, needs a valid visa and, second, to enter the country should get a visa from the authorities. Regarding to this point, it becomes evident that the authority to permit the entrance of foreigners to Iran is within the government's competence. It seems necessary to mention that the competence of the government has been recognized. And the competence of the government in connection with granting visa i.e. entry permit to the country, is considered a voluntarily competence. In other words, if there is a possibility of damage from entering a foreigner to the country, government can refrain from granting the entry permit i.e. visa to the foreigner. But from law standards and also international law point of view, the government's competence in granting passport to its nationals is considered a capacity of incumbency unlike the mentioned competence. It means the government cannot refrain without legal reason from issuance of passport, in other words if the government refrains without legal reason from issuance of passport, there must be the right to objection for the beneficiary to the government's action according to the concerned laws (Motamani Tabatabai, 2003).

Therefore, Iran's law by focusing on government's sovereignty principle with different reasons such as security issues, public interests and hygiene considerations concerning exerting some restrictions and limitations on accepting foreigners and their staying in the following cases grants the cabinet the authority to:

- $\quad$ Preventing from all or part of the import and export at the border

- Forbidding temporary or permanent residence, or moving from some regions of the country

- Adopting special tools of controlling the foreigners in extraordinary cases 
Effect of human rights and international law on tourism law in Iran: Every tourist before travelling and becoming a tourist, relying on being a God's creature, has rights and privileges that travelling and exiting the homeland, do not cause to be deprived of these privileges and human rights.

In all territories, human enjoys natural rights and its related basic principle including freedom and security principle and his/her freedom and security must not be threatened. Today, with generalization of tourism and creation of appropriate grounds for travelling in different countries and establishing UNWTO, the meaning of tourism has changed and tourists in addition to their natural rights have enjoyed new rights and special privileges.

Changing the concept of tourism and creation of new chapters for tourism are mainly because of codification and approval of regulations related to human rights and the obligation of its execution in countries which are the members of the UN. In this direction, the effect of civil societies, international unions, formal tourism organizations and decisions made in international communities including suggestions of 1963 conference of UN in Rome and finally suggestions of 1088 conference of Vancouver, Canada and more importantly, increasing the recognition of canon law were remarkable in this ground" (Mohaghegheh Damad, 1998).

In a nutshell, tourism has such a potential which can be very useful and effective in building a world full of peace.

Codification of new laws for tourist and its recognition in all countries must be performed through international communities or international unions of formal and tourism organizations and by considering the viewpoints of all member countries of the UN and by coordination and cooperating of UNESCO. After its final approval, should be entered into the constitution and ordinary laws of the members and be stressed on its execution.

Regardless of the establishment of tourism affairs office in 1936 for facilitating and regulating of the tourism affairs in former Iran's interior ministry, which was replaced by supreme council of tourism in 1947 and then according to a written authorization, establishment of tourist attraction organization and then joint-stock company of tourism facilities, essentially by approving the law of founding of tourism and information ministry in 1975 and its establishment, tourism affairs were addressed more seriously.

Description of the tourism regulations approved in recent 50 years, details of duties of organization and institutions related to tourism and reforms made to them, receiving performance of tourist attraction organization (established in 1962) and former tourist council and performance of education centers of tourism services including hotel management schools and school of tourism services and information and finally evaluating the performance and activities of former information and tourism ministry is not possible here and not necessary as well, but in order to deal with tourism law and privileges in Iran, here is a rapid tool at the latest regulations after the victory of Islamic republic, i.e., development of tourism and Iran touring law, approved in September 1992 and its executive regulations. The anticipated privileges in this law for tourists and tourism include:

A. Individual or direct privileges

B. Indirect privileges and in connection with creating appropriate grounds for tourism

A. The privileges considered for the tourists:

- Enter and exit of conventional personal equipment with exerting customs exemptions

- Exit of handicrafts or allowed products made in the country with observing related regulation

- Exit of book and publications for non-commercial uses

- Use of special customs facilities

According to relevant regulations, every tourist can take the following equipments when exiting the country:

- Personal jewelry

- Photography camera, One

- Non-professional video camera, One

- Binoculars, One

- One portable musical instrument

- Caviar, stamped or sealed by Iran's joint-stock company of fishery, $3 \mathrm{Kg}$

B. Privileges considered in connection with creating suitable grounds for tourism:

- Requiring banks to investment in private and state sector with industrial interest and rate for development of Iran touring and tourism

- Requiring municipalities, ground organization and forests and rangelands organization and relevant organization in order to provide ground for Iran touring and tourism facilities

- Issuing any kind of permits for establishment of travelling agencies and Iran touring and tourism facilities 
- Receiving costs of fuel, water, electricity, charges, taxes and bank loans at the rate of industry sector

- Returning hotels and travelling facilities centers seized by different authorities to ministry of Islamic culture and guidance for operation and providing the needs of tourists in legal due time

- Obligating the embassies and overseas political agents of Islamic republic of Iran in order to provide facilities and performing issuance of travelling visa services for nationals of countries having political relations with Iran, in maximum of 10 days

- Requiring all officers controlling the entrance and exit of foreign nationals like officers of passport, customs, airport, railway station, ports based at the enter and exit bases of borders and cities to create necessary facilities of tourists

- Requiring civil aviation organization, ports and shipping organization and organization of terminals, customs and railway to provide proper location for establishment of information and tourism offices at the enter and exit bases inside the cities

- Embedding boxes in temporary storage based at the borders for storing goods allowed or not allowed to be entered belonged to tourists

- Establishing necessary facilities and providing appropriate services by Pilgrimage and Haj Organizations in order to holding pilgrimage tours, including sending Iranians to overseas historical places and also entering pilgrims from other countries to visit pilgrimage places of Iran by using the mentioned facilities

- Establishing, developing and operating appropriate Iran touring and tourism facilities and also providing necessary devices for individual and collective travelling of domestic and foreign tourists inside Iran, including by ground, air, sea and providing services and necessary measures for presenting the country's progresses and introducing Iran's cultural developments, civilization and attractions by ministry of Islamic culture and guidance, according to law of goals and duties of Islamic culture and guidance, approved in 1987

Tourists' duties: Each tourist for requesting and enforcement of his/her right, foreseen in different rules and regulations, or known according to evident custom and usage of each civil society, has mutually duties which must fulfill it. These duties are as follows:

- Observing rules and orders of the host country

- Respect to culture, traditions of the host country
- Protecting environmental and natural resources during travelling

- Protecting parks, zoos, national buildings and monuments, museums and other cultural resources.

- Supporting individuals with motivation to advancement of tourism and inviting them to travel with peace

- Avoiding from unpleasant actions and activities such as gambling, prostitution, drinking alcohol and other illegal acts or other vice actions

- Not using luxury and ornamental goods as much as possible

- Avoiding from going to dangerous places

- Obeying guidance orders of local guiders and officers

Rights of non-Muslim tourists in Islamic countries: An in Juridical book, a right of non-Muslims, in one way, has been classified into three groups:

- Zemmi

- Moahed

- Mostaman

Zemmi: If those groups of non-Muslims who are "Ketabi", i.e., Jewish, Christian and Zoroastrian, want to accept nationality of a Islamic country as religious minorities and citizens and be allies of Muslim nation and sign "Zemmeh" treaty with Islamic government and remain committed to the treaty and undertake "Zemmeh" terms such as paying ransom, they are known as "Zemmi". Concluding a treaty between "Ketabi" and Islamic government has terms and therefore creates a series of rights between "Zemmi" and government and Islamic nation. "Zemmi" is considered a citizen of a Islamic country and enjoys privileges and facilities of Islamic government and country equally as a Muslim citizen and like Muslims live under the support of Islamic government and his/her life, property, honor is respected and protected by society and, mutually, he/she is obligated to preserve the rites and respect to constitution of Islamic society. On one hand, in connection with personal affairs and family life such as marriage, divorce, inheritance, he/she can act according to his/her custom by observing a series of measures and balances mentioned in the text of the treaty and signed by the two parties (Mohaghegheh Damad, 1998).

There are many discussions about "Zemmi", some of them will be mentioned when discussing differences between "Zemmi" and "Mostaman". 
"Moahed": "Moahed" are non-Muslims who have signed a non-aggression and peace treaty with Islamic government and live in another territory inside their country. Signing a treaty causes their life, property, honor and territory be respected and secured and if the political and social interests of the Muslims require, Islamic government can give them the permission to enter and stay by issuance of visa based on the rules and regulations and travel to Islamic country according to the allowed duration granted to them by interests and rules of the country as a businessman, tourist, student, ambassador, charge d'affaires and counselor and other ordinary and formal titles.

"Mostaman": "Mostaman" is an unbeliever who has sought quarter and asylum and pleaded to enter to Islamic country in order to study about Islam and Islamic and cultural ideas to get familiar with regulation and knowledges of religion or other non-malicious motives. Each one of the three non-Muslim groups: "Zemmi", "Moahed", "Mostaman" has rights that will be discussed in a separate chapter.

Non-Muslim rights in an Islamic country: NonMuslim groups who have entered a Islamic country according to the terms and regulations and measures of the treaty signed with Islamic government and keep committed to all written cases in the treaty of the agreed treaty, they have rights in Islamic society which observing their rights is compulsory for government and citizens as they stay as citizen or a guest whether a businessman or a tourist in Islamic country and have not breached their treaty. Including:

- All-inclusive immunity and security of life, property, dignity and job: nobody has the right to offend and harass them. If they are offended, Islamic government is obligated to protect their rights and support them. Robbing their properties is unlawful and creates liability and their rights and properties must be returned by relevant legal authorities. Their tools and instruments and economic and research activity places which has the work permit according to the law must be secured against any offence

- Enjoying freedom to perform their religious tasks and holding national and religious ceremonies:

- Attendance in temples and religious places, whose existence is recognized by law, such as "Keneset" and performing practices and religious rituals are allowed provided that preserving the reverence of sanctum of Islamic society
- Freedom of performing their regulation and personal affair according to their rites, such as drinking wine and eating pork, on the condition that be done in privacy and in closed places belonged to them and if they do these kinds of abnormal behaviors evidently and in the society and in full view of Muslim people, they will be treated according to Islamic rules

- They are free to trade with Muslims and attendance in business market. Any betrayal in transaction with them is unlawful and forbidden

- Insulting to them and swearing at their sanctities is forbidden. Of course, respecting them in a way that causes the Muslims be annoyed and belittled is inadmissible

- In disputes, conflicts and complaints, they are treated justly in Islamic law courts (Mohaghegheh Damad, 1998)

There are series of subjects that are in the field of discretion of Islamic government's responsibility, like buying and selling ground or investment and establishment of farming and industrial companies and building, which depends on the discretion of Islamic government and the governing principle to all of these kinds of activities is to guard the lofty principle of Islamic dignity and interests of Muslims.

Here, to explain the Islam's emphasis on rights of non-Muslims in Islamic society and country, some marginal of the issue is also mentioned:

- If a Muslim destroys a property belonged to an unbeliever who lives under the protection of the Islamic country, he is liable to damages. For example if a Pig kills a "Zemmi" or spills a "Zemmi's" wine, supposing that he/she was not drinking wine or eating pork obviously or if seize a property belonged to a "Zemmi" or an unbeliever who live under the protection of Islamic government he/she is liable and must return it to his/her owner

If a non-Muslim signs a treaty with a Muslim or an Islamic government to stay in an Islamic country, this treaty is correct and valid. If an unbeliever, after concluding a treaty and staying for some time in a Islamic country return to his/her homeland country and the aim is to trade or convey a message or for leisure and intends to return to the Islamic country, security and peace treaty does not expire and whenever he wants to return, he is safe, but if he/she returned with the intention to live in the foreign country, security treaty concerning he/she is null and 


\section{J. Social Sci., 6 (3): 340-349, 2010}

void, but if he/she has left a property or wealth in the Islamic country, his/her property and wealth will be secured and if requests by message to return it, the property must be returned.

\section{CONCLUSION}

The collection of regulations related to tourism includes basic tourism law. This law determines the tourism development policies, organizing duties, structure and resources of financing the national tourism office. Various special laws are also codified. These laws are codified in connection with standards, qualifications of obtaining permit and inspection events of hotels, tourism restaurants, travel agencies, tour guides and other tourism institutions. These laws have been provided carefully and on the basis of recognition of the country's or region's needs. Necessary preparations and office capabilities must be provided to continuous execution of these laws. Some trends to control and managing standards of industry must be anticipated in the collection of laws.

Tourism development in many countries is because of the presence of tourism areas, natural parks and historical and ancient regions. Execution of law concerning preserved parks and regions in order to protect them is considered vital. Many countries have provided the laws to support from tourism consumers. These collections of laws have been designed to support from tourists against the mismanagement of irresponsible institutions.

After doing studies and reviewing legal supports of tourists in Iran from two dimensions of internationally and internally, it can be concluded concerning the hypothesis of the article that although there are two different attitudes in international law towards to freedom of travelling and accepting foreign nationals to the country, but majority of the countries do not show any tendency to unconditional freedom of foreign nationals. Thus, in some countries including Iran, for different reasons such as regional unity and tourism treaties, the idea of granting more liberties to them has developed. In Islam, there are different views towards the national and foreigner that at present cannot be accepted according to standards of international law.

From Islam's point of view, foreigner is referred to a person who is not Muslim. Thus, all Muslims of the world can be considered as nationals. It seems Muslims do not have any obvious limitations on travelling in Islamic countries. Foreigners, also, by obtaining "Aman" (quarter), provided for themselves freely travelling or temporary staying in Islamic country. In fact, "Aman" is considered as travelling permit and temporary stay in Islamic country and is synonymous with today's visa. In a way it is a kind of seeking asylum. It means "Mostamen" was under the protection of Islam according the same treaty of immunity. Regarding the two mentioned aspects, policies of Iran's government in connection with rights of tourists, by focusing on principle of government's sovereignty gives authority to the cabinet to exert some restrictions on accepting foreigners and their stay for different reasons such as security issue, public interests and hygienic considerations.

Changing the concept of tourism and creation of new chapters for tourism are mainly because of codification and approval of regulations related to human rights and the obligation of its execution in member countries of the UN. As a result, it can be stated in the direction of the article's hypothesis that because of long history of Iran in the subject of tourism, there have been written or unwritten law in this area. In the historical trend of laws there have been ups and downs that depend on the attention of the government to the subject of the tourism. Thus, it can be admitted that because of historical record of Iran in the field of tourism, it had a very long record in the field of rules and regulations for tourists. And these rules and regulations could not be ignored whether in the past or at present and consider the legal supports for tourism in Iran totally poor. Although, given that laws are function of time and place, so many of our written or unwritten laws have been changed, completed or destroyed. And regarding that, at the present time, the subject of tourism has been considered scientifically and as a profitable industry in postmodern era by many countries. And given that it is an economical industry, in order to get its considerable success, codified and very effective laws must inevitably be used. And it should be in the direction of consent of tourists, protection of cultures and rites and customs of the host community and sustainable development view.

In this connection, to codify necessary laws for tourists and maintaining the content of tourists and increasing efficiency of the industry, paying attention to international rules and regulations, human rights and conventions between governments is vital. Therefore, ignoring these variables, do pose Iran's tourism industry rules and regulations in an appropriate position and this has caused our country, which is among the highly potential tourism countries for competition in the international arena, gains little income from this economic activity. 


\section{REFERENCES}

Cooper, C. and R. Shepherd, 1998. Tourism, Principles and Practice. 2nd Edn., Longman, New York, ISBN: 0582312736, pp: 1100.

Dinari, A., 2006. Urban Tourism in Iran and World, Mashhad. Vajeganeh Kherad Publication, ISBN: 964-8931-26-7, pp: 56-63.

Gee, C.Y. and E. Fayos Sola, 2000. International Tourism: A Global Perspective. Translated by Parsaiyan, A. and S.M. Arabi, Publications Office of Cultural Research, Tehran, ISBN: 964-6269-095, pp: 255.

Ghanami, O., Y. Samadi and S. Cheraghchi, 2008. Codex, Regulations and Treaty Cultural Heritage, Handicrafts and Tourism. Publications of Cultural Heritage Handicrafts and Tourism, Tehran.

Gratner, W.C., 1996. Tourism Development: Principles, Processes and Policies. John Wiley and Sons, New York, ISBN: 0471284475, pp: 560.

Hall, C.M. and S.J. Page, 2006. The Geography of Tourism and Recreation Environment, Place and Space. 3rd Edn., Routledge, London, New York, ISBN: 0-415-33560-4, PP: 2426.

Hataminejad, H. and M. Shabanifard, 2007. System theory and application development in urban tourism management control system. Shahrdariha J., $\quad 87:$ 12-18. http://www.magiran.com/magtoc.asp?mgID $=1108$ $\&$ Number $=87 \&$ Appendix $=0$

Jafari Tabrizi, M.T., 2007. Universal Human Rights from Islamic and Western View Points. Publications Office Legal Services, Tehran, Islamic Republic of Iran, ISBN: 964-6608-31-0, pp: 462.

Jansen, M. and E. Lievois, 2002. Analyzing Heritage Resource for Urban Tourism in European Cities, In: Business and Economics, Contemporary Issues in Tourism Development, Pearce, D.G. and R. Butler (Eds.). Routledge, London, New York, ISBN: 0415271673, pp: 288.
Kazemi, M., 2007. Tourism Management. Publication SAMT, Tehran, pp: 13.

Khaliliyan, S.K.H., 1984. Islamic International Law. Publications Office Publication of Islamic Culture, Tehran, pp: 136.

Mohaghegheh Damad, M., 1998. Collections Tourism Conference Islamic Republic of Iran. Publication Kish, Kish Island Iran, pp: 29-88.

Motamani Tabatabai, M., 2003. Civil Liberties and Human Rights. University of Tehran Press, Tehran, pp: 33.

Nasiri, M., 2004. Private International Law. 10th Edn., AGAH Publication, Tehran, pp: 105.

Page, S.J. and C.M. Hall, 2003. Managing Urban Tourism. Prentice-Hall, Harlow, ISBN: 0130272868, pp: 202-216.

Papoli Yazdi, M.H. and M. Saghai, 2009. Tourism: Tourism (Nature and Concepts). SAMT Publication, Tehran, ISBN: 964-530-086-X, pp: 233-235.

Taghavi, M. and M. Akbari, 2009. Introduction to Urban Planning and Tourism Management. Alavi Publication, Isfahan, pp: 164-170.

World Tourism Organization, 1995. UNWTO technical manual: Collection of Tourism Expenditure Statistics. Publication World Tourism Organization. $\quad$ pp: 1-1. http://pub.unwto.org/WebRoot/Store/Shops/Infosh op/Products/1034/1034-1.pdf

Ziyaye Bigdeli, M.R., 2002. Public International Law. 18th Edn., Publication Gnjeh Danesh, Tehran, ISBN: 964-5986-15-x, pp: 33. 